\title{
CENTRALIZATION OF ISSUING THE BINDING TAX LAW INTERPRETATIONS
}

The current tax law interpretations have been functioning in the Polish tax law since January 1, 2005. The assessment of the two-and-a-half years' period of the principles regulating the binding tax law interpretations indicates that the solutions to this problem have not been ideal. The number of faults and imperfections hindered their practical application. The evidence for this situation is the jurisdiction of administrative courts. The system of issuing interpretations at the level of tax offices, however, led to many discrepancies within the same factual states which were to be assessed in the same way. A matter of question was also whether a tax organ could issue an interpretation related to the future of a hypothetical situation.

The necessity of complex reform of the entire institution, including even the elimination of its present standards from the legal relations, was also pointed at by the Constitutional Tribunal ${ }^{1}$.

The cure for such disorder was supposed to be the amending law ${ }^{2}$ of November 16, 2006 passed by the Polish Sejm, effective of January 1, 2007, excluding, inter alia, the regulations amending the system of issuing official tax law interpretations. The carried amending law (effective of July 1,2007) transferred, issuing the binding interpretations of the tax law to the competencies of the Minister of Finances.

As the taxpayers filed tens of thousands of applications calling for interpretations every year, it was certain that the department of finances would not be able to deal independently with issuing such a great number of interpretations. The legislator had envisaged the situation then that the Minister of Finances could authorize by decree its subject organs to issue individual interpretations on the Minister's behalf, and within the specified scope, stating at the same time the material and local jurisdiction of the authorized organs.

Wyrok Trybunału Konstytucyjnego z dnia 30.10.2006 r. P/36/05, OTK ZU 2006/9A poz. 129

Ustawa z dnia 16 listopada 2006 r. o zmianie ustawy - Ordynacja podatkowa oraz o zmianie niektórych innych ustaw (Dz. U. Nr 217, poz. 1590) 
The Ministry of Finances took advantage of the possibility to transfer the issuing of interpretations into the hands of heads of some tax offices. According to the Ministry of Finances' decree ${ }^{3}$ the heads of tax offices in Katowice, Poznań, Warsaw and Bydgoszcz were authorised to issue individual interpretations.

Article $14 \mathrm{~b} \S 6$ of the Tax $\mathrm{Law}^{4}$ therefore appoints the special mode of authorisation of tax organs to issue individual interpretations. It must be pointed out that including the said authorisations into the means undertaken in order to ensure uniformity of the aforesaid interpretations, is rather surprising, all the more that considering the fact that the change resulting in the transfer of competencies to issue individual interpretations to the Minister of Finances was justified by the need for standardisation of the law by the tax authority. The justification of the government bill draft on changing the Tax Law bill and on changing some other bills, implied that in the opinion of the authors of the draft "decreasing the number of offices authorised to issue the interpretations will contribute to the uniformity of law by the tax authority and will facilitate the general supervision of the matter for the Minister of Finances".

However, the change in the scope of jurisdiction of the organs authorised to issue individual interpretations did not comprise all tax organs. Such competence is still with the authority of local government officials, the mayors (city presidents), starosts or voiveodeship marshals, who issue the interpretations according to their jurisdiction.

The way of standardising of the mode of granting authorisation to issue individual interpretation in art. $14 \mathrm{~b} \S 6$ of the Tax Law raises doubts about the real nature of the legal structure accepted in this law. The form of the act by which the authorisation is granted (decree of the Minister of Finances) as well as its statutory components seem to indicate that what is concerned here is the transfer of jurisdiction. Nevertheless, the authorized tax organ issues individual interpretations on behalf of the subject which granted the authorisation, but within the limits of local and material jurisdiction purposefully designated. The tax organ then issues those interpretations within its "own competency". Revoking the authorization granted according to art. $14 \mathrm{~b} \S 6$ requires waiving the decree by which it had been originally granted.

Another decree by the Minister of Finances ${ }^{5}$ introduced an application form to apply for interpretations in individual cases of tax payers and the way of payment for the application. This is a complete novelty in the Polish tax legislation which

3 Rozporządzenie Ministra Finansów z dnia 20 czerwca 2007 r. w sprawie upoważnienia do wydawania interpretacji przepisów prawa podatkowego (Dz. U. Nr 112, poz. 770)

Ustawa z dnia 29 sierpnia 1997 r. Ordynacja podatkowa (tj. Dz. U. z 2005 r., Nr 8, poz. 60 ze zm.)

Rozporządzenie Ministra Finansów z dnia 20 czerwca 2007 r. w sprawie wzoru wniosku o wydanie interpretacji przepisów prawa podatkowego oraz sposobu uiszczenia opłaty od wniosku (Dz. U. Nr 112, poz. 771) 
deserves a positive assessment. A large number of applications submitted in the previous legal circumstances did not meet the elementary requirements for such applications. Taxpayers, in mostly handwritten applications, did not present the actual situation and did not include their own legal assessment of the given actual situation. Therefore, the applications for interpretation, being formalised, were complete and included all elements required by law. Undoubtedly this solution contributed to the facilitation of the process of granting interpretations by the Minister of Finances.

New regulations on interpretations are aimed at ensuring the uniformity of tax law applications. They enable to obtain the interpretation of the actual and future situation. Also the catalogue of people authorised to obtain individual interpretations was broadened. A third party in the understanding of art. 110-117a of the Tax Law may apply for the interpretation as well as a person who resides or lives out of the Republic of Poland.

After amending the law taxpayers may ask about not only the actual present situation but also about the tax interpretation of the business activities planned in the future.

It must be noted that the broadening of the scope of interpretation by the future events is in a way the expression of taking into account the doctrine which for a long time had indicated the purposefulness of such a regulation being introduced.

In the application for interpretation a tax payer must thoroughly present the actual situation, the situation which occurred or an event which will take place - as before - the taxpayer's own point of view in relation to the case. New interpretations are issued in one-instance proceedings. It might potentially accelerate the final settlement of the case by shortening the time between receiving an unfavourable interpretation and hearing the case by court. However, the applicants were left without the right to have their case re-heard by a higher instance.

The area of friction between the applicants and the Minister of Finances may be the possibility to prolong the period to issue an interpretation according to art. $139 \S$ 4 of the Tax Law. In cases when the suspension period or the time for the applicant to carry out certain procedures is not included in the three-month period, the periods which prolong the proceeding should not raise any major disputes. Their length is determined in proper decisions and calls from tax offices. However, if the Minister of Finances intend to refer to the delay caused by the party or for reasons independent of the tax organ, there may appear disputes whether the delay was actually caused independently of the tax organ, and how long was the delay period independent of the minister of public finances. 
A novelty in the proceedings related to issuing individual interpretation is the duty imposed on the taxpayer to make a statement under the threat of penalty for false testimony.

From July 1 to December 31, 2007 the Offices of National Tax Information (Biura Krajowej Informacji Podatkowej) received merely 10.233 applications. Not all of them, however, were replied to. Individual interpretations were returned to as many as 4.406 taxpayers. And it is still unknown of how long was the standard threemonth period for issuing the interpretation prolonged. To make a comparison it can be added that in the first half of 2006 applications for interpretation were submitted by 32.674 taxpayers. The data provided leave out no illusions: taxpayers do not trust interpretations issued according to new principles.

A question arises whether and to what extent the major decrease in the number of applications and issued interpretations is due to the change of the organ and to what extent is it due to the changes introduced on July 1, 2007. These changes include, for example, the fees for application (PLN 75 for each actual situation).

In the view of the majority of legal experts, calling the tax interpretations binding at present is a joke. Prior to the expiry of the period of limitation there might be a check up at a company, interpretation may change and the company will have to pay the tax arrears. Therefore, as experts say, it is better not to file for an interpretation. And this all is due to the change in law which restricted the advantages of interpretations existing so far (i.e. prior to July 1, 2007), most of all due to the liquidation of the retroactive protection against tax payment and binding force for the tax organs. Prior to the change the interpretation was binding for the tax organ and did not allow any contradictory decisions.

In the new legal environment a tax organ holds the right not to take into account the interpretation while dealing with a tax case.

It does not mean, however, that the taxpayer can no longer take advantage of the protection provided by such an interpretation. The scope of protection, though, depends on the type of individual interpretation. The broader scope of protection is related to the interpretation of future actual situations.

The narrower scope of protection, which worries taxpayers, is provided by the interpretations of future situations.

According to experts, it is due to this change, inconvenient for taxpayers, that the tax interpretations, which three years before were thought to be the greatest achievement of the law on free business activity, lost their effectiveness and taxpayers' interest after July 1, 2007. Responsibility for the poor law was once again shouldered by the taxpayers. 
Complying with the faulty interpretation which was subsequently changed results in tax payment exemption on two conditions:

1) The obligation was not correctly fulfilled due to the compliance with the interpretation which was later changed,

2) The tax consequences related to the event reflected by the actual situation being the subject of interpretation took place after the publication of the general interpretation following the delivery of the individual interpretation.

The change of faulty interpretation exempts the taxpayer from paying the tax only temporarily. The exemption in paying the tax due and not paid on the grounds of the faulty interpretation comprises the period of the tax calculation. For example, in the case of annual tax it is the period to the end of the tax year in which an altered general interpretation was published, the changed individual interpretation was delivered or the tax organ was provided with the copy of the administrative court decision in force waiving the individual interpretation.

What does this state of matters result in? The taxpayers have stopped applying for tax interpretations. The decreasing trend is growing. In the first quarter of 2008 only seven thousand applications were submitted. Also the significant increase in the application fee is also a case in point. Each application is subject to PLN 75 fee. It has to be paid within 7 days from the day of filing the application. The application for interpretation not paid for is left unattended. If the taxpayer presents in the application several actual situations to be dealt with, each situation must be paid for separately.

Another problem is a still increasing number of complaints on tax interpretations. This problem was dealt with in 2008 by Wojewódzki Sąd Administracyjny (Provincial Administrative Court) in Warsaw. It was all due to the changes in principles of issuing written interpretations. The proper organ to issue individual interpretations is the Minister of Finances, who transferred his competencies to four authorized heads of tax offices. However, it does not change the fact that just one court has the jurisdiction to deal with the complaint lodged in relation to the Minister of Finances' interpretation which is the WSA in Warsaw. Unfortunately, it soon turned out that the new interpretations cause a new problem. Within merely four months in 2008 Department III of the WSA in Warsaw was burdened with additional 237 complaints. It is the consequence of the regulation which makes one single organ, the Minister of Finances, to issue the interpretations . It clearly results from the general principles of the law Prawo o postępowaniu przed sqdami administracyjnymi ${ }^{6}$ (Law on proceedings before administrative courts). 
However, these regulations cause problems both to taxpayers and tax officers. All complaints are dealt with by the WSA in Warsaw. It forces representatives of tax offices and taxpayers from all over Poland to come to Warsaw for trials. It might be a problem for courts, too for if there are too many complaints, the time of dealing with them by the WSA in Warsaw will be prolonged.

The Ministry can see the negative consequences of the centralization of issuing tax interpretations. It is considering pledging the President of Supreme Administrative Court to consider special solutions allowed by art. 13 item 3 of the law Prawo o postepowaniu przed sqdami administracyjnymi. According to this article the President of the Republic of Poland May by his decree transfer hearing cases of specified nature belonging to the jurisdiction of another court to the provincial administrative court. Therefore, the needed change may take place without involving the Sejm. The introduction of changes in this matter is justified, especially that the Minister of Finances is the author of the interpretation only formally. In practice, they are actually prepared by the four tax offices.

There are a few possible solutions. The matter may be left as it is, but sooner or later it will lead to undesirable situations (i.e. prolonging the time of dealing with the case by the WSA in Warsaw). Having in mind the accessibility of the court to the citizen, it would also be possible to use administrative courts nearest to the complaining taxpayer's residence. The best compromise would be, however, to designate four WSAs, corresponding with the heads of revenue offices to whom the minister transferred his competences. This would allow to maintain the uniformity in judicial decisions as far as interpretations are concerned.

Almost always changes in regulations bring about consequences unforeseen by their authors. That was the case also with the interpretations. Dealing with all the cases in Warsaw means not only difficulties in participating in the trail. There arises a problem of the return of costs of tax administration functioning.

The Ministry of Finances indicates that in Warsaw there is an Office of Legal Services and Proceeding Substitution (Biuro Obsługi Prawnej i Zastępstwa Procesowego). Therefore it is possible to substitute without the necessity to delegate tax office employees, if the number of cases requires so.

However, a person who wants to appeal against the tax interpretation must go to Warsaw for a trial. It is hard to find a reasonable justification of this regulation.

The poor quality of the tax regulations and frequent changes cause problems to taxpayers, tax organs and administrative courts. Will the Polish taxpayer live to see the times when there is no need to issue tax interpretations? It would be so simple if a businessman could focus on running business activity and to calculate the tax and would only need to know the income. 


\section{Streszczenie}

Celem regulacji standaryzujących wiążące interpretacje prawa podatkowego jest zapewnienie ujednolicenia stosowania przepisów prawa podatkowego. Obowiązujące od dnia 1 lipca 2007 roku zmiany w tym przedmiocie ograniczyły znaczenie funkcjonujących do tej pory interpretacji - przede wszystkim z powodu likwidacji ich retroakcyjnej mocy i wiążącego charakteru dla organów podatkowych. W obecnym stanie prawnym zakres ochrony przyznanej w ramach dokonanej wykładni zależy od rodzaju indywidualnej interpretacji. Szerszy zakres ochrony odnosi się do interpretacji okoliczności, które mogą zaistnieć w przyszłości. Zmiana w tym zakresie spowodowała, że podatnicy przestali wnioskować o interpretacje podatkowe. Odpowiedzialność za złe prawo została ponownie przerzucona na podatników. 